\title{
CULTURALLY SPECIFIC WORDS AND THEIR TRANSLATION (EXAMPLES ON THE MONGOLIAN WRESTLING APPARELS)
}

\begin{abstract}
According to Tsedev Kh. Ph D. there are four main translation methods for translating culturally specific words from one language into another language: ways of transcription, verbal translation, substitution of synonyms, and interpretation. Culturally specific words cover a wide range of areas such as religion, customs, clothing, articles, housing, food, and the historical and cultural aspects of the people. Therefore, we aimed to do translation on examples of Mongolian national wrestler apparel and other relevant accessories. English speakers are not well acquainted with Mongolian culture, especially with Mongolian Naadam and Mongolian wrestling. In this article we aim to do an attempt in translating Mongolian wrestling apparel related realia using interpreting method and in letting English speakers know about Mongolian wrestling apparel.
\end{abstract}

Keywords: Realia or culturally specific words, wrestling, translation, apparels

In this paper, we considered the basic translation methods for Mongolian culturally specific words as examples of the Mongolian national wrestling apparel from dictionaries. Translation study is a young, controversial science, and they have been trying to answer the eternal question of how to translate. The researchers have been paying close attention to the various subjects of translation.

Translators often face the needs to translate realia words/ culturally specific words from any culture in their every step. Most of them don't have suitable equivalents of translating variations for other cultures. Therefore, they are considered the main challenge that a translator faces in the process of translation when a reference in the source language is made to a situation absent in the experience of the group of people speaking the target language, i.e., when the source language contains so-called realia.

The culturally specific words (realia) are all tangible, and the dictionary defines them as «materially cultural things». In linguistics and translation studies, often the words of these cultural objects have often been taken into account, as well as words and phrases, are also considered as national special words. These words can be strange to some people and are sometimes hard to understand. They are reflected in customs, clothing, articles, housing, food, utensils, and transportation. They also reflect the life, religion, as well as the historical and cultural aspects of the people.

There are plenty of culturally and ethnic specific words in any language that are used by their own speakers. The Mongolian wrestling silk apparel with fibro seam and fiber ropes tied round the stomach of the wrestler and other pieces of wrestling costume is clear proof [eleg-büs]. This rope is so strong that no one can break it. There are no weight classes. Wrestlers of all weights can fight against each other by grabbing any part of his opponent's wrestling costume, including the fiber ropes tied around the wrestler waist. There are no age limits or time limits in a match.

Mongol wrestling is the kind of wrestling which allows the participants to gain a hold/get a grip [Gankhuyag Ch,2002:83] by both the opponent's apparel and body parts to topple the opponent using his own legs, hips and arms incorporate pushing, lifting, tripping and other techniques using the lower body and upper body part. It is suitable to organize everywhere, both outdoors and indoors. It means that the apparel plays crucial role in this wrestling. No one does the translation in this area.

We aimed to collect culturally related words or realia covering Mongolian wrestling apparel words and tried to translate them into English find translated materials and make comparing in this paper work. The Mongols have translated many books in Tibetan for a long time in centuries of history. Among other things, three different methods of translating literary items have been developed. One of these three approaches is the method of transliteration, the other is summarized translation, and the third is the way to imitate [Buyandelger Kh, 2016:158]. As we know that doing realia translation is very difficult and complicated issue. We found less translated names from a dictionary issued by Mongolian National University [Mongolian National University Press printing "Concise Dictionary of cultural Expressions", 97-98.]. Therefore, we searched the internet for materials. We also didn't succeed much. As we have large materials in Mongolian and are hosts of this culture, we do our best to make English spoken people understand this realia. Many Mongols have studied Mongolian wrestling from different angles such as which parts of Mongolia have more 
national-ranked wrestlers, how many wrestling techniques they used, how they prepared for their wrestling, how they strengthened their physical development, etc.

The Mongolian wrestling apparel are real and complex items rooted to Mongolian culture and also part of world wrestling culture. Their names are culturally specific words because all objects are origin, and the dictionary defines them as "material culturally things" [[Mongolian National University Press printing "Concise Dictionary of cultural Expressions", 97]. Realia or culturally specific wrestling apparel words can be translated in ways of transcription, calculation, verbal translation, substitution of synonyms, interpretation [Tsedev Kh. Some issues of translation theory and practice. 2018: 84]. That's why we aimed to reveal these difficulties from the target language into English.

ScD. Kh. Bayanmunkh, (A researcher of Mongolian wrestling) Undefeatable Giant, wins 10, "Mongolian national wrestling is a comprehensive knowledge and experience, culture and life-dream of Mongols self-consuming its nature, climate and economics through historical stages. Mongolian National wrestling is the treasure that was created by Mongols and intellectual property of Mongols" [translated from Bayanmunkh Kh, . Features of physical development of Mongolian wrestlers. 1994:53].

Mongolian wrestlers wear such clothes: Mongolian wrestler hat with залаa-[zalaa] — red silk or hair tuft or tassel on a hat, нөмрөг: — [nӘ:mrӘg] /a gown/ zodog, shuudag, gutal.... etc. They are all tangible. We can see, touch, wear, and even buy. However, the tricks of wrestlers to topple his opponents are intangible.

а. Бөхийн малгай — [bukhiin malgai] — A wrestler hat -Four side velour Mongolian wrestler hat has a pointed top with red tassels. The hat symbolizes the spirit of its owner.

According to the decree of Mongolian President (1994), Mongolian Wrestlers who have accomplished the 5th round and other higher rounds have been awarded red tassel dedicated to mark his accomplishment on them and distinctive badges on both their own national deels and hats. The soum-titled wrestlers wear small round hat badges with tassels, province titled wrestlers wear bigger squire hat badges with symbol representing his rank and rank medal. The state-titled wrestlers wear bigger round hat badges on their own hats and title medals representing their ranks with tassels. Lower rank wrestlers respect higher ranked ones.

b. Бөхийн малгайн залаа: - [bukhiin malgain zalaa] - hat tassels — fixed to a hat the back hanging along the shoulders - Ranks in Mongolian National Wrestling can be noticed when they are in their wrestling apparel or in national deels [Davaasambuu Go. Translation and related terminological glossary. 2001:.24].

c. Нөмрөг: - [nü:mrüg] /a gown/The first wrestlers who have the highest ranks standing at the beginning of both right and left flanks wear silk gowns above his own wrestling apparel.

The wrestlers standing on left flanks wear light blue ones the right ones red silk like gowns. The front sides are open, round-necked, and sleeved with framed silk.

d. Элэг бүс [ileg büs] — Fiber ropes tied round the stomach of the wrestler. The opponent wrestler can hold it to make him fail. It should be rounded to the size less than a fingernail. If the wrestler defeats, he unties and goes under the winner's raised armpit.

e. Зодог-ог далбаа: — [zodog] / dalba:] A tight, collarless, heavy-duty longsleeved jacket of red or blue color. Traditionally it was made of wool, but modern wrestlers have changed to looser materials such as cotton and silk. The front is open but tied at the bottom with a simple string knot, exposing the wrestler's chest.

f. Wyудаz: — [shu;dag] — Small, tight-fitting briefs made of red or blue colored cloth. These make the wrestler more mobile and prevent an opponent from taking advantage of long pants to get a better grip [Gankhuyag Ch. 2002:83]. Both zodog and shu:dag are sewn with 5 or more straight line quilting that make the apparel durable and not to be torn easily. The straight line quilting are made in the middle space of both zodog and shu:dag as well. As Bayanmunkh Kh. noted in his dissertation there are over 660 tricks in Mongolian wrestling [Bayanmunkh Kh. 1994: 54]. They do at least three tricks by holding a grip from his opponent's zodog and shu:dag using either both hands or a hand.

g. Гутлын түруҮний боолт - [gutli:n turu:nii bo:lt] — There is leather strings with oval shaped leather between 15-20 cm thin and national ornaments on it, for each Gutal. That prevent taking off when the wrestler wrestles.

h. Гутал - [gutal]: High leather boots, the traditional style gutal are often reinforced around the sides with leather strings for the purpose of wrestling.

i. Гутлын оймс: - [gutaliin oims]: - Earlier days Mongolian wrestlers used to wear knitted or felt leggings defending on seasons for their feet. Present days, they use socks from any firms.

j. Гутлын хүлэг: — [gutliin huleg]: / nogt/: — halter rope. The traditional style gutal (with slightly upturned toes), have often flat soles. They cause slipping problems when they wrestle outdoors on grass 
covered land on the carpet in doors. Therefore, wrestlers initiated one more leather string for avoiding from slipping especially during rain or thick green grass in summer time.

k. Энгрийн ялгах тэмдэг: — [Tsolnii engriin temdeg] — badge of the tittle ranks. They wear special distinctive badges/ medals on their deels that represent their victories in Naadam wrestling festivals which year is no matter. From the fifth round till the final round each wrestler receives distinctive badge medal figured his own title shape badge on it.

1. Малгайн ялгах тэмдэг: - [malgain yalgah temdeg] — A distinctive badges of Mongolian wrestler hat - They also wear the special round, silver badge figured his own title shape badge on his own hat. The national champions wear goldish distinctive badges depending on their own achievement. If he wins the Naadam two times he becomes a National champion. If he wins the Naadam three times he gains one more hat badges on his hat. If wins one more, he receives one more badge, etc. You will see that the Mongolian grand champions have full of badges on each four sides of their hats.

There are 21 provinces and their 333 soums (small administrative divisions) in Mongolia celebrate their own festivals. Within these three days, 333 soum area wrestlers have each their own festival champions, and 21 win their own province festivals and one wrestler wins the national Naadam.

When doing the culturally specific words' translation, we have encountered the following difficulties:

- Having profound knowledge on the subject of the area.

- Next thing is to have the same knowledge about religion, tradition, rituals of the culture.

- Having obtained a high level of expertise in the language of the translation.

- Having ability to use the appropriate translation method.

As mentioned above, there are four main translation methods for translating Mongolian realia into Russian: ways of transcription, calculation, verbal translation, substitution of synonyms, interpretation. These methods are suitable for translating from any languages. Many English speakers are not well acquainted with Mongolian culture especially with Mongolian Naadam and Mongolian wrestling. So we consider that it is better to translate Mongolian wrestling apparel related realia using interpreting method. In this article we aim to do an attempt in translating Mongolian wrestling apparel related realia using interpreting method and in letting English speakers know about Mongolian wrestling apparel.

\section{Bibliography}

Bayanmunkh Kh. Features of physical development of Mongolian wrestlers. Ulaanbaatar, 1994. 54 p.

Buyandelger Kh. Directing attention to the issues of studying history on Mongolian national wrestling apparel. Ulaanbaatar, 2016. 158 p.

Gankhuyag Ch. Mongolian and English Dictionary. Ulaanbaatar, 2006. 83 p.

Davaasambuu Go. Translation and related terminological glossary. Ulaanbaatar, 2001. 24 p.

Tsedev Kh. Some issues of translation theory and practice. Ulaanbaatar, 2018. 84 p.

Mongolian National University Press printing “Concise Dictionary of cultural Expressions”. P. 97-98. 